\title{
Editorial
}

\section{O simples como inovação}

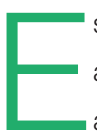

se usarmos a navalha de Occam 1,2,a para analisar nossas realizações tecnológicas recentes? Pode-se argumentar contra, uma vez que o reducionismo é incompatível com inovações disruptivas - nossa atual tendência, pois, "para todo problema complexo, existe sempre uma solução simples, elegante e completamente errada"3. Por outro lado, até o nosso mais simples gadget do dia a dia parece "gritar" que a simplicidade - no uso, na concepção, no formato, etc. - é o caminho. Estamos acostumados com a ideia de que a teoria mais simples é a mais elegante e, provavelmente, a mais correta, ou, no mínimo, mais adequada. Mas estamos igualmente submersos num mundo complexo e multifacetado.

Como de praxe, Albert Einstein parece ter a solução do dilema, já que "tudo deve ser feito da forma mais simples possível, mas não mais simples que isso"b, por que não verificar se estamos usando a abordagem mais simples, porém sem perda de eficiência, para atuar na complexidade do mundo atual? Neste contexto, o que têm em comum o desenvolvimento de um spinner de baixo custo e o uso em testes de OLEDs de recipientes de vidro semelhantes aos da sua cozinha? São realizações de profissionais comprometidos com o século XXI, o que torna a área de ensino da Revista muito bem representada neste número. Esses pesquisadores burlaram as dificuldades usando criatividade mesmo num cenário inóspito.

Sem ensinar de modo simples, mas não simplificado, a complexidade do mundo moderno, como esperar dos profissionais formados uma caracterização extensiva das condições de plasma ou mesmo sua simulação? Ou que construam reatores versáteis a partir de ampolas de vidro ou peças mecânicas que, embora diminutas, suportem esforços mecânicos intensos? Quanto à tecnologia de vácuo, sempre é possível um novo problema ou uma nova abordagem, por exemplo, com a preocupação com o uso de frutos e seus resíduos de produção de modo sustentável. Assim, a obtenção de resveratrol a partir do bagaço da vinicultura pôde ser otimizada a baixas pressões

O recipiente em que se testa um OLED é semelhante àquele em que se produzem novos materiais ou se obtém com pouca degradação um produto natural. Rotas paralelas, caminhos semelhantes, ao fim e ao cabo: interatividade.

Maria Lúcia Pereira da Silva

Editora-chefe

a. A Navalha de Occam, princípio metodológico que aconselha a parcimônia e simplicidade nas explicações, é bastante conhecida através da expressão Entia non sunt multiplicanda praeter necessitatem (As entidades não devem ser multiplicadas além do necessário), frase cunhada por John Ponce, ou seja, o princípio requer que o menor número de premissas possível seja utilizado para explicar qualquer fenômeno.

b. Há controvérsia sobre a autenticidade dessa citação; por exemplo, Quote Investigator (internet. 2011. Disponível em: https://quoteinvestigator. com/2011/05/13/ einstein-simple), indica tratar de citação indireta, ou seja, "Einstein pode ter criado o aforismo, mas não há evidência... sendo Roger Sessions responsável pela propagação". De qualquer modo, a citação está presente no livro de Calaprice (Calaprice A. The expanded quotable Einstein. Princeton: Princeton; 2000) e em muitas publicações de renome.

\section{REFERÊNCIAS}

1. Reductionism: Occam's Razor, Reductionism, Monism, Reduction, Type Physicalism, Dialectical Monism, Separation of Concerns. [s.l.]: General Books; 2010.

2. Garrett AJM. Ockham's Razor. In: Grandy WT, Schick LH, editors. Maximum Entropy and Bayesian Methods. Fundamental Theories of Physics. Dordrecht: Springer; 1991.

3. Mencken HL. Prejudices: Second Series. [s.I.]: Alfred A. Knopf; 1920. 


\section{Simplicity as innovation}

W hat if we use the Occam's razor ${ }^{1,2, a}$ to evaluate our recent technological accomplishments? A reasonable argument against this idea is the fact that reductionism and disruptive innovations - the main tendency nowadays - are contradictories because "explanations exist; they have existed for all time; there is always

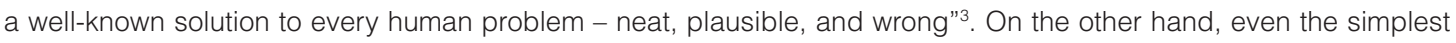
gadget of day by day life seems to "cry out" that simplicity - in design, use, form, etc. - is the correct way. We are used to the idea that the simplest theory is more elegant, and probably the correct one, or, at least, more adequate. However, we are likewise submerged in a complex multifaceted world.

As usual, it seems Albert Einstein has the solution to the dilemma, since "everything should be made as simple as possible, but not simpler"b, why not to be sure that we get the simplest approach, although without lack of efficiency, to interact with the complexity of the modern world? On such scenario, what does it have in common the development of low cost spinner and the use on OLED devices tests of glass recipients quite similar to the ones present on regular kitchens? These are accomplishments of professionals committed with the $21^{\text {st }}$ century, which greatly enhances the Education session of this RBAV issue. These researchers broke the hindrances of a harsh scenario by the use of creativeness.

Without teaching in a simple way - but not only by oversimplification - the complexity of modern world, how can it be expected from graduate people a comprehensive plasma characterization or even a plasma simulation? Or the manufacturing of versatile reactors by the use of glass ampoules let alone tiny mechanical pieces that endure intense mechanical stress?

Regarding vacuum technology, it is always possible a new problem to solve using new approaches; for instance the sustainable production using fruits and these residues. Thus, resveratrol extraction from the winemaking pomace could be optimized in low pressures.

The recipient used on OLED devices testing is a similar conception to the reactor for production new materials or the one where natural products are obtained with minimum degradation. Parallels routes, similar paths, after all: interactivity.

Maria Lúcia Pereira da Silva

Editor-in-chief

a. Occam's Razor, a methodological principle that advises parsimony and simplicity on explanations, is well known by the expression Entia non sunt multiplicanda praeter necessitatem (Entities should not be multiplied without necessity), phrase coined by John Ponce, i.e., by principle it should be used the minimal amount of premises on the explanation of any phenomenon.

b. There is some controversy regarding the authenticity of this Einstein citation, for instance, Quote Investigator (internet. 2011. Available from: https://quoteinvestigator. com/2011/05/13/einstein-simple) states that the sentence is an indirect citation, i.e., "Einstein may have crafted this aphorism, but there is no direct evidence in his writings... Roger Sessions was a key figure in the propagation of the saying". Nonetheless this quote appears in the book presented by Calaprice (Calaprice A. The expanded quotable Einstein. Princeton: Princeton; 2000) and several other prestigious publications.

\section{REFERENCES}

1. Reductionism: Occam's Razor, Reductionism, Monism, Reduction, Type Physicalism, Dialectical Monism, Separation of Concerns. [s.I.]: General Books; 2010.

2. Garrett AJM. Ockham's Razor. In: Grandy WT, Schick LH, editors. Maximum Entropy and Bayesian Methods. Fundamental Theories of Physics. Dordrecht: Springer; 1991.

3. Mencken HL. Prejudices: Second Series. [s.I.]: Alfred A. Knopf; 1920. 